\title{
REMARKS ON RECENT CATALOGING EFFORTS AMONG SYRIAC MANUSCRIPTS PRESERVED AT THE HILL MUSEUM \& MANUSCRIPT LIBRARY $^{1}$
}

\author{
AdAM C. MCCOLLUM \\ HILL MUSEUM \& MANUSCRIPT LIBRARY, SAINT JOHN'S \\ UNIVERSITY
}

\begin{abstract}
The Hill Museum \& Manuscript Library (HMML) possesses, among other things, the largest collection of high quality digital copies of Syriac manuscripts in the world. Since 2003, HMML has been actively working with institutions and individuals in Lebanon, Turkey, Syria, Iraq, and Jerusalem to preserve their manuscript collections and make them more widely available to scholars. Cataloging is underway and this paper highlights some recent discoveries out of these collections.
\end{abstract}

1 This paper in an earlier form was the basis for a talk I gave at the North American Syriac Symposium at Duke University in 2011. I would like to emphasize that the details highlighted here are current with the time of that presentation and thus do not reflect subsequent finds and cataloging work. 


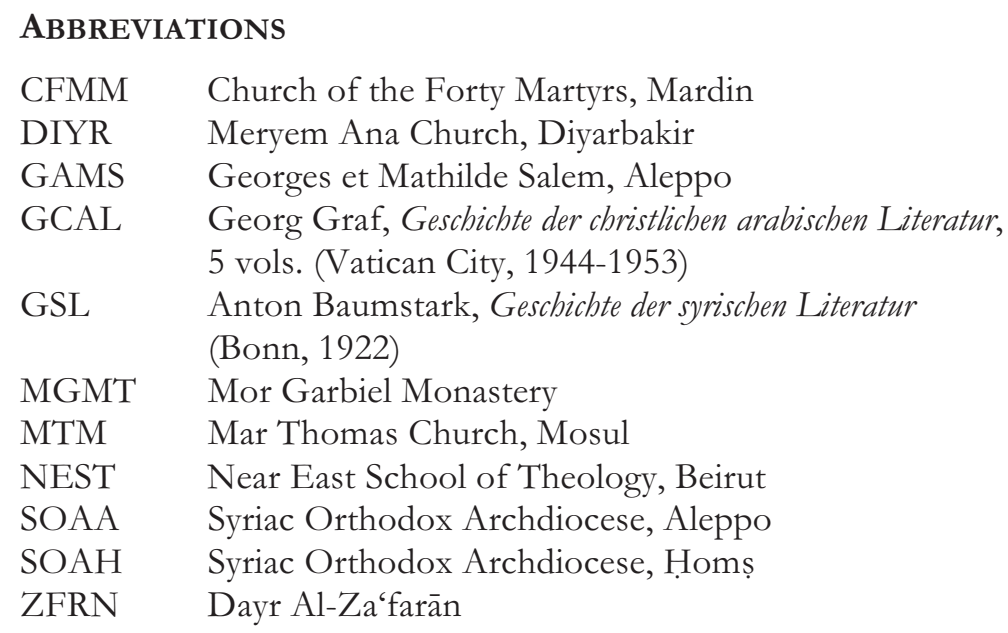

\section{INTRODUCTION}

My purpose here is to make some specific remarks from the perspective of a cataloger on some Syriac collections available for study at HMML that, for the most part, are currently being cataloged by me or other catalogers, and secondly, to highlight a few items, several newly discovered, that will perhaps be significant for the study of Syriac literature. Here at the outset, I am happy to point out that there is a fine tradition of status reports on the cataloging of eastern Christian collections at HMML, begun by William Macomber in the 1970s for our Ethiopian microfilms and more recently continued by Fr. Columba Stewart. I hope that this is only the first of several such reports, each replete with particulars signaling the potential advancement of our field, that I will be able to take part in giving to you and the rest of the community of scholars working on texts in eastern Christian languages.

\section{SOME GENERAL REMARKS ON CURRENT CATALOGING WORK}

Before devoting our attention to some specific texts recently cataloged or at least noticed in HMML's collections, some remarks are called for regarding the collections now being or lately having been studied. These are, first of all, Dayr Al-Za'farān, the Church of the Forty Martyrs, the Monastery of Mor Gabriel, the Meryem Ana Church in Diyarbakir, and the Syriac Orthodox Archdiocese of Homṣ. You will note that only one of these collections is outside 
of Turkey, and that they are all West Syriac repositories. In addition, I will also mention below a few manuscripts from the Syriac Orthodox Archdiocese of Aleppo and the Mar Thomas Church in Mosul. While I will be speaking specifically about our born digital collections, I should also highlight the fact that there is a modicum of Syriac manuscripts available on microfilm from European libraries with which HMML worked in previous decades; a preliminary list of these Syriac materials was drawn up by HMML's former director Julian Plante in 1991. Visiting scholars to HMML may study all of this material on-site, whether it has been cataloged or not, digital or microfilm, and manuscript copies may also be ordered, subject to the approval of the owning library.

How does one identify a manuscript? The minimal answer, of course, is by city and library, and by shelfmark. While the city is indisputable-allowing, at least for names to change due to shifts in political and social attitudes-library and shelfmark are hardly fixed and inviolable means of identification! The Mor Gabriel manuscripts, in fact, do not even have obvious shelfmarks physically attached to them; for this reason, it is, perhaps, following the course of good counsel to recommend that they henceforth be referred to by their HMML source numbers. The Dayr Al-Za'farān manuscripts are another case entirely: rather than suffering a lack of shelfmarks, they are brimming with identification numbers from various periods and by various custodians, some manuscripts having as many as five different numbers! While cataloging the collection, I spent time producing a concordance of these numbers which I hope will solve at least a few manuscript location problems in the future and will save researchers from fruitless searching, and all of these alternate shelfmarks are included in the current catalog records. The most recent numbering system used at Dayr AlZa'farān is identical to that of the HMML source numbers.

A point must also be made about manuscript migration, that is, the movement of manuscripts from one place to another. In an ideal world, colophons and other notes would supply us with details about the when, where, and why of such book movements, but it is not an uncommon case that, lacking these details, we must merely surmise. A number of notable examples of this appear when we peruse Dolabani's Dayr Al-Za'farān catalog and compare it with that collection at the time it was photographed by HMML. Fortunately, the large and nearby collection at the Church of the 
Forty Martyrs, also in Mardin, very conspicuously has many manuscripts formerly located at Dayr Al-Za'farān. The main evidence for this is the seal and bookplate for the latter monastery adorning several books now belonging to the former.

Before turning directly to some specific textual finds among HMML's collections, I would like to touch on something of a more personal and directly codicological note. An advantage of any large manuscript collection is the possibility of getting to know rather well the scribes responsible for that collection, and HMML is no different. I name here just three scribes, all from the twentieth century, at least two of which names will almost certainly be known to many of you. First, Philoxenos Yuhannon Dolabani (18851969), bishop of Mardin until his death, ${ }^{2}$ is known especially as a Syriac Orthodox educator and scholar; HMML has several manuscripts having some connection to Dolabani, and an example of his handwriting can be seen below in Figure 3.

A lesser known name is that of Barșawmā bar Malke; his very neat script would make an easy introduction to Syriac handwriting for any student (see Figure 4 below).

Finally, most of us will be familiar with the hand of Julius Yeshu' ('Isāa) Çiçek (1941-2005), thanks to the facsimile printings of manuscripts copied by him that the St. Ephrem Monastery in Holland has published. It is no surprise that there are copies Çiçek made among HMML's West Syriac collections. See Figure 5 below for a colophon written by Çiçek at 19 years of age in 1960 from a Mor Gabriel manuscript.

See also in Figure 6, from a 1964 copy of some works of Moše bar Kēfā, Çiçek's signature in Arabic and in Latin script at the end of a colophon written in Syriac.

\section{SOME SPECIFIC TEXTS AND AUTHORS}

I would like, first of all, to highlight the nuance of the title "recent finds" as I am using these words. The nature of HMML's collection being what it is, some having been previously known and cataloged, some not, now is a suitable time both to offer a snapshot of the Syriac collections available at HMML that have already been known, and thus to confirm, for example, that this or that manuscript is still available, but also to draw attention to genuinely

${ }^{2}$ A short note on his death will be found in MGMT 189, p. 174. 
new finds, that is, copies of texts that have otherwise been wholly or mostly unknown. Information about such texts is, of course, of the utmost significance for broadening our knowledge of Syriac literature generally, and specifically for moving toward the publication of text editions and translations, as well as for possibly calling for new collations of already published texts. ${ }^{3}$

I will speak here mostly with regard to genres that I have interest and experience in, which is to say, I mostly stay away from liturgical manuscripts; only one subgenre will be briefly mentioned. Of liturgical manuscripts there is, unsurprisingly, a very great number, and many of these date well into the twentieth century. While there is perhaps something of note in these liturgical codices, even the later ones, I leave that investigation to someone more qualified.

As in every language and tradition of eastern Christianity, that of hagiography in Syriac remains a field ripe for research, even in terms of that most basic activity of academic enquiry, the publication of text editions. I need not even remind you that the still indispensable Bibliotheca Hagiographica Orientalis is now over a century old, and that Peeters and his fellow Bollandists there only gave indication of published texts, understandably leaving hagiographic manuscript indices to other scholars focusing on particular languages. While I have personally come across more saints' lives in Garšunī than in Syriac, I will point out here simply that there are several hagiographic manuscripts among the collections so far being cataloged. ${ }^{4}$ Incidentally, even for those saints' lives readily available in Syriac thanks to the volumes prepared by Bedjan, it is no secret to anyone who has used any of those texts that new editions are desirable, ${ }^{5}$ and, of course, the

3 Some of the details presented here are based on prior cataloging work of CFMM by Abdul Massih Saadi and Grigory Kessel's recent work on DIYR. The other information given below is based chiefly on my own cataloging and manuscript research.

${ }^{4}$ For example, MGMT 26, 134, 153; MGMT 129 (cf. CFMM 463) has a long book on Pachomios translated into Syriac by Dolabani; Mar Dado (which one?) in ZFRN 217, MGMT 135; Mar Awgen in ZFRN 385; in ZFRN 380, is a story of a prostitute taught by Serapion.

${ }^{5}$ It is, for example, generally unclear what the source for the listed variants is, or even whether the variants are attested in manuscripts or Bedjan's own emendations. 
more well known these and other hagiographic manuscripts are, the better position we will be in to improve this situation.

The only overtly liturgical genre of texts I will mention here is that of anaphorae. As you all know, Syriac Orthodox tradition is particularly rich in its production and preservation of their numerous anaphorae. While there are really only a few that are or were commonly used - a fact also reflected in manuscript copies available at HMML—-there are nevertheless several anaphorae that remain unpublished and are worth the attention of liturgists and scholars of Syriac poetry. There is a checklist of anaphorae by Barsoum $^{6}$ and in 1988 Brock provided a list of published anaphorae, ${ }^{7}$ but a more detailed index of anaphorae building on these two lists is desirable. It might include manuscripts, title in English and Syriac, incipits, and perhaps other information. Such an index might easily be started with the materials available at HMML. 8

The study of original Syriac or Syriac-Arabic/Garšunin lexica has been a part of Syriac studies for several centuries. There is not a single page of Payne Smith's Thesaurus that lacks testimony to such lexicographical research, and many of us have perhaps spent hours perusing the works of Bar 'Ali and Bar Bahlul in the editions, respectively, of Hoffmann and Gottheil, and of Duval. There were, of course, other dictionaries available and many of these continued to be copied into the twentieth century. Among some important finds in collections available at HMML, the following may be singled out.

The famous lexicon of Bar 'Ali (second half of 9th century), just mentioned above, remained a popular lexical text, and HMML has copies possibly from as early as the 15th century and reaching into the 20th: CFMM 466 (dated 1856 AG [ $=1544 / 5$ CE]); CFMM 467 (dated 1913 AG [= 1601/2 CE]); CFMM 468 (15th c.?); CFMM 470 (15th c.); CFMM 471 (17th c.); ZFRN 194 (20th c.). Naturally, these later manuscripts are not valuable in the ordinary text-critical sense, but since lexical texts are especially

6 The Scattered Pearls: A History of Syriac Literature and Sciences, trans. Matti Moosa (Piscataway, 2003), pp. 65-67.

${ }^{7}$ Ephemerides Liturgicae 102: 436-445.

${ }^{8}$ For example: SOAH 33, 42, 44; MGMT 19, 49, 116, 117, 137, 139, 148, 149, 156, 158; DIYR 30, 33, 42, 54, 56, 66, 74, 79, 87, 93, 98; CFMM 613-618. 
susceptible to scholarly accrual, those interested in the activity of later Syriac scholars having to do with language will very probably find some additions and changes of interest in manuscripts like these.

The Kitäb al-Turjumàn of Eliya of Nisibis (975-1046), a SyriacArabic lexicon arranged according to theme, was published by de Lagarde and even earlier by Thomas Obicini, but in an undesirable form. A new edition is a definite desideratum, and I have identified four previously unrecognized manuscripts, all of which are important for one reason or another. From Aleppo (SOAA 123) comes a manuscript dated $1835 \mathrm{AG}(=1523 / 4 \mathrm{CE})$, which is, as far as I can tell, the oldest dated manuscript known. Two undated, but certainly relatively early manuscripts come from the Church of the Forty Martyrs (CFMM 489 and 490), and from the same place comes a late manuscript, but one which is significant because it has a third column for many words in Syro-Turkish. ${ }^{9}$ These copies are all in Syriac script.

I will say a little more later about the works of Maphrian Basilios Šem ūn Al-Ṭurānī (c. 1670-1740), but in this mention of lexica it is fitting to name his abridged Syriac and Arabic/ Garšūnī lexicon. I here point out ten manuscripts of this work recently found in HMML's collections: ${ }^{10}$

- Six manuscripts from CFMM, nos. 473-478.

- DIYR 70 (1791)

- ZFRN 199 (1889)

- SOAH 17 (1902)

- MGMT 4 (1960) (does not seem to be identical to the other texts)

All of the manuscripts I have seen of the lexicon are Syriac and Garšunin, except one: the 19th century manuscript CFMM 473 uniquely has the Arabic parts in Arabic script rather than Syriac.

9 It should be pointed out that there are mistakes in Baumstark's information, and Sinai X41N has been incorrectly identified as a copy of the Kitäb al-Turjumān (Philothée du Sinaï, Nouveaux manuscrits syriaques du Sinaï [Athens, 2008], pp. 243-244).

${ }^{10}$ For some other manuscripts, see Barsoum, Scattered Pearls, p. 518, n. 5. 
The four oldest manuscripts mentioned (CFMM 474, 476, 477; DIYR 70) here all have a bolon at the end in which the author is clearly named, but in one of those (CFMM 474) the author is referred to in the third person, but the others have the author himself speaking in the first person. As to the date of composition, CFMM 476 and 477 have the date $2030 \mathrm{AG}(=1727 / 8 \mathrm{CE})$ in the Lolon, but Barsoum differently gives the date 1724 (no source cited). Finally, the later manuscripts (CFMM 478; SOAH 17; ZFRN 199; MGMT 4) do not specify the author at all. While an edition of this work is not necessarily a pressing desideratum, students and scholars interested in Syriac and Arabic lexicography and in the interactions between these two languages will probably welcome news of still more witnesses to the text, particularly those witnesses that seem to reach back to the century of its composition.

The last lexical text to mention is that associated with the name Eudochos (or Eudoxus); this text seems to have been studied very little by modern scholars. There are four copies available merely at the Church of the Forty Martyrs (CFMM 482-485). ${ }^{11}$

I will say nothing of the pet poet of Syriac studies, Ephrem, because I am unaware of any real significant discoveries or textual confirmations for him in recent work among HMML's manuscripts, but the case is different with Jacob of Serug. As many of you know, not all of Jacob's surviving memre have been published, and most of those that have been published are not available in critical editions of any kind. I will not venture into the important and necessary question of determining the authenticity of works attributed to Jacob, but whatever the means to do that may be, it will surely have to rely on a corpus as complete as possible of good editions, so further work on the Syriac text of Jacob's poems is clearly called for. Among important Jacobcollections, I point out two manuscripts in our repository, neither, however, previously unknown: DIYR $3^{12}$ and MTM 74(6).13 These

${ }^{11}$ Cf. GSL pp. 294-295, and William Wright, A Catalogue of the Syriac Manuscripts Preserved in the Library of the University of Cambridge, Vol. 2 (Cambridge, 1901), pp. 991-993, with references there to other manuscript catalogs.

12 See A. Vööbus, Handschriftliche Überlieferung der Mèmrē-Dichtung des Jaq'öb von Serūg, vol. 2 (Louvain, 1973), pp. 72-80. 
manuscripts and their easy availability are exciting not only for the prospect of an improved textual witness to published texts, but they, and others with them, also beckon researchers to work on the unpublished poems attributed to Jacob. There are, for example, several copies of his Memra on Death and Gehenna; ${ }^{14}$ a 19th-century manuscript, ZFRN 48, in addition to the aforementioned poem, also has two other unedited poems attributed to Jacob: one On the Departed and one On the Hour of Death. ${ }^{15}$

While every scholar even partly interested in Syriac literature has probably dealt to some extent with Syriac poetry and has perhaps even found some pleasure in it, there are still scores of pages of Syriac poetry that have yet to be studied beyond the cadre of scholars stemming from the communities that produced it. The easy availability of manuscripts from those communities will, it is hoped, broaden exposure to these works. I first point to a 20thcentury manuscript (MGMT 85) with several poems by Nuh the Lebanese (1451-1509), which, despite an edition by Dolabani (Mardin, 1956), are still not widely available in any published form. The same manuscript also has a copy of the edition of Bar 'Ebrāyā's poems by Dolabani (Jerusalem, 1929), and another 20thcentury manuscript of the famous maphrian's poems is known from Dayr Al-Za'farān (ZFRN 36, dated 1928). More importantly, from Aleppo are two older manuscripts of his poems (SOAA 114 and 148), alongside other content, the earlier dated to 1360, the later to the fifteenth or early sixteenth century at the earliest (since it also contains something from David Puniqāyā d. ca. 1500 and Sergius of Hāḥ, d. 1508).16

13 A. Vööbus, Handschriftliche Überlieferung, vol. 4 (Louvain, 1980), pp. 76-83.

14 On this memra cf. BO I:315, no. 67. These copies are mostly Syriac, but at least one manuscript also has an Arabic translation of the whole text in the margins (ZFRN 62).

15 For the former memra, cf. Yuhanna Dolabani's Catalogue of Syriac Manuscripts in Zafaran Monastery (Mardin/Piscataway, 2009) p. 54, and for the latter, pp. 282 and 324.

16 Cf. Hidemi Takahashi, Barhebraeus: A Bio-Bibliography (Piscataway, 2005), pp. 320 and 323. In SOAA 148 (pictured above), the poem "On Perfection" ends with the date 1588 AG (=1276/7 CE) on f. 20 r, but this is for the composition of that particular poem, not for its being copied. 
Another manuscript from Aleppo (SOAA $114 \mathrm{M}$ ), perhaps somewhat more recent, also contains some of Bar 'Ebrāyā's poems, as does an 18th-century manuscript from Beirut (NEST S 4). ${ }^{17}$

The aforementioned 20th-century manuscript from Dayr AlZa'farān also has some poems of Bar 'Ebrāyā's contemporaryand one with whom his poetry has sometimes been confusedJohn bar Ma'dāni (d. 1263), as does another 20th-century manuscript, this one from Mor Gabriel (MGMT 201). ${ }^{18}$ Despite the importance of the just pointed out older manuscripts from Aleppo of Bar 'Ebrāyā's poems, these later copies are admittedly not very stimulating, but there are, on the contrary, a number of poetic texts by lesser known, unstudied, and unpublished authors from more recent centuries now accessible at HMML in a number of anthology manuscripts: seven from Dayr Al-Za'farān (ZFRN 40, $48,52-55,393)$, one of which is almost identical to another from the Church of the Forty Martyrs (ZFRN $40=$ CFMM 144), and one more for Mor Gabriel (MGMT 201). All of these are very late manuscripts: the last dated one has the year 1971! I have time to name only a few authors and titles, but I hope with this litany of names to do two things: to reveal the breadth of poets known so far from just a few manuscripts, and to pique your interest in an almost unplowed field of study. All of the authors I am about to name are found in the most expansive of the manuscripts I just mentioned, ZFRN 40 (= CFMM 144), and several of them are found in the other manuscripts as well. ${ }^{19}$

- David Puniqāyāa (Al-Himṣî)

- Thomas Puniqāyā (Al-Himṣị̂) 20

- Hannanyā Aksənāyāā

17 See the brief catalog record for the manuscript in The Near East School of Theology Theological Review 3 (1981): 118.

${ }^{18}$ From the end of the 19th century, also contains a copy of what is probably John's most well-known poem: On the Vanity of the World (ff. 95v-103r).

${ }^{19}$ I have indicated some references (Baumstark or Barsoum) for the poets that are perhaps lesser known. Most of them are also mentioned in Cardahi's Liber Thesauri de Arte Poetica Syrorum (Rome, 1875).

20 Little seems to have been written on this author, but he is mentioned by Barsoum, Scattered Pearls, p. 29. 
- Maphrian Bar Qiqi (d. 1016)22

- Jacob ‘Urdnsāyā²3

- Behnam Hadlāyāā24

- Yešu‘ bar Hayrun (d. 1335) ${ }^{25}$

- John bar Andreas26

- Timothy of Gargar ${ }^{27}$

- John Isma'ili28

- Michael the Syrian ${ }^{29}$

- Jacob of Barțelle ${ }^{30}$

- John of (Bet) Sbirinā̄31

- John (Sa'īd) bar Șabūnīîn

${ }^{21}$ On the author (d. 1493), see Baumstark, GSL, p. 327.

22 See Barsoum, Scattered Pearls, p. 414.

23 On the place name from which this adjective is derived, cf. Bar 'Ebrāyā, ChrEccl, vol. 3, col. 561 (cited in PS col. 2846). The village is located between Midyat and Hāh (I thank Andrew Palmer for this information).

${ }^{24}$ For the author, see Baumstark, GSL, p. 327.

25 See Barsoum, Scattered Pearls, pp. 489-490.

26 See Baumstark, GSL, p. 294 for the author.

${ }^{27}$ See Baumstark, GSL, p. 191. In the ms, the author is said to have died in 1169.

28 Every line of his poem in ZFRN 40 ends with an adverb. The author died in 1365 according to the manuscript. He was the nephew of Ignatios b. Wahīb (on whom see Graf, GCAL II:271).

${ }^{29}$ The poem is On the Accidental Death of Mar John, Bishop of Mardin; see A. Vööbus in OC 55 (1971): 204-209.

${ }^{30}$ The author, who died in 1241, is also known as Jacob (or Severos) bar Šakko. There are two poetic letters in these manuscripts in which each line of each letter begins with the same letter of the alphabet ( $p \bar{e}$ in one, taw in the other).

31 There is an Acrostic Memra on the Capture of Tur 'Abdin. See on the author (and this poem), Barsoum, Scattered Pearls, p. 516.

32 Memra on Jacob of Serug, on which Robert Kitchen is giving a paper at this Symposium. The poem is dated here in the manuscript to November 1143, but this is a mistake; see Barsoum, Scattered Pearls, pp. 421-422, for 
- Habib of Edessa ${ }^{33}$

- Philoxenos Zaytun of Anhel ${ }^{34}$

- Timothy Pawlos of Edessa ${ }^{35}$

Only briefly do I mention that almost fifty pages of poems by the famous Church of the East author 'Abdišo' bar Brikā (d. 1318) are available in a late manuscript from Mor Gabriel (MGMT 201, pp. 167-215), including:

- Memra on the Lamentations of the Older Son over the Prodigal Son

- Acrostic Sogitha on Repentance

- Acrostic Poem on the Resurrection and the World to Come

- Acrostic Poem on the Saying "Man is a Microcosm (Little World) and the World a Great Man"

\section{- Hexaemeron Poem}

Turning to the genre of science, there is one particularly exciting discovery. F. Nau's 1899 edition (and Margoliouth's 1932 translation $^{36}$ based on that edition) in the Journal Asiatique of Severos Sebokht's Treatise on the Astrolabe lacks part of section 19 and all of sections 20 and 21. To my knowledge, these parts of this work have remained unknown to this day, but I am happy to say that they are completely intact in CFMM 553, an undated manuscript perhaps of the 18th or 19th century. The publication and translation of these hitherto missing sections of Severos' work should be a matter of top priority to those Syriac scholars engaged in the study of scientific texts.

I again turn to another genre: that of biblical exegesis. Of the biblical commentaries of Dionysius bar Șlibi (d. 1171), those for

a discussion of the work. The author is not named in this manuscript, but is known from other sources.

${ }^{33}$ Memra on Jacob of Serug; see Barsoum, Scattered Pearls, p. 262.

${ }_{34}$ Memra on the Controversy (1849) with Metropolitan Anton. It says in ZFRN 40 that the author died in 1855. See further Barsoum, Scattered Pearls, p. 522.

35 Memra on the Calamity and Murder of 1908, the author is said in the rubric to have died in 1915.

${ }^{36}$ In R.T. Gunther, ed., Astrolabes of the World (Oxford, 1932). 
several biblical books remain unpublished. The Old Testament commentaries, divided into "material" (N) (م) and "spiritual" (A/o), especially stand in need of publication: only the commentary on Pss 73-82 and the spiritual commentary to Ecclesiastes have been published. For the New Testament, it is the commentary on Paul's Epistles that remains unedited. Several late manuscripts available at HMML (SOAH 12, 13, 15; ZFRN 22; MGMT 81, 86) preserve some of the texts, and while they are late manuscripts, they are nevertheless easily accessible and certainly worth the study of anyone contemplating research on the exegetical work of Dionysius bar Slibi.

It is no surprise that HMML's collections bear relatively sizable witness to the prolific and varied output of Gregory bar 'Ebrāyā. There are copies, many late, of a number of his works, including the Book of the Dove (in Syriac and Garšunīi), the Ethicon, and both his longer grammatical work The Book of Rays and the shorter metrical grammar. ${ }^{37}$

I have seen two manuscripts of Bar 'Ebrāyā's Laughable Stories, both from the Church of the Forty Martyrs. CFMM 441 was begun in Gargar in 1941 AG (= 1602/3) and completed in Amid the following year, ${ }^{38}$ and CFMM 461, dated 1960, is a copy by Dolabani based on two copies, one from the beginning of the seventeenth century, the other from 1908. Both of these copies had lacunae, Dolabani tells us in the preface to his copy, and he also mentions Budge's edition of 189739 and a partial edition by Isaac Armalet. ${ }^{40}$ In both manuscripts the work is entitled فجه:تيا: which may be unique. ${ }^{41}$ This important work certainly

${ }^{37}$ For the latter, CFMM 500 (1791 AG [= 1479/80 CE]); CFMM 503 (15th c.?); CFMM 505 (15th c.?); CFMM 506 (15th c.?); both works are together in CFMM 495 (1888 AG [= $1576 \mathrm{CE}]$ ).

${ }^{38}$ See f. 115 r.

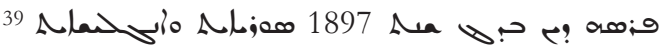

${ }^{40}$ No edition by Armalet is listed in Takahashi, Barbebraens, pp. 347353.

${ }^{41}$ That is, Respelendent Stories. This is different from the adjectives

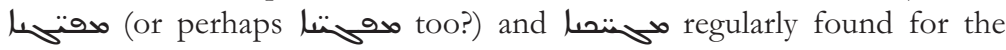
title. 
needs both a new edition and English translation, ${ }^{42}$ and the older, at least, of the two manuscripts just mentioned merits definite consideration in that endeavor.

I have come across one copy of Bar 'Ebrāyā's translation into Syriac of Ibn Sīnā’s إلاشارات والتنبيهات, called in Syriac بمات بمرات مدست: (MGMT 20). This manuscript is somewhat unique in that the Syriac translation was clearly intended to be accompanied by the Arabic original (probably Garšūni), but the second column remains vacant. A complete edition of the work remains unpublished, so this manuscript, even though it is late, may be added to the list of those to be consulted by anyone interested in Arabic influence on Syriac philosophy in the 13th and subsequent centuries and of course for an edition of this Syriac version, which, in Hidemi Takahashi's words, "could be of value as an indirect thirteenth century witness for the text of the Išarat, as well as being, for Syriacists, a hitherto unexploited source for lexicography." 43

As an example of a later text that might be of interest both for the development of Syriac Orthodox theological expression, as well, of course, as for the later-in this case, 15th century-use of Syriac, I point to a work of Ignatios La'zar bar Sābtā, Patriarch of Turabdin (d. 1481/2), known as Abū Al-Ma'ānī: a theological work

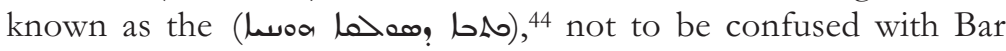
'Ebrāyā's astronomical work with the same name; the work is mentioned a few times by Barsoum but is unpublished.

In connection with lexica I mentioned above Maphrian Basilios Šem‘ūn Al-Ṭurānī (c. 1670-1740). In addition to his dictionary, I would like to point out also a few other of his works available in our collections. At the Mor Gabriel Monastery is a late copy of his Syriac Book of Theology (MGMT 59, dated 1964). Although I am speaking to Syriac scholars, I cannot refrain from

42 I have translated into English the "vulgar" parts of the book only given in Latin in Budge's edition, but my work has not yet been published.

${ }^{43}$ In Reisman and Rahim, eds., Before and After Avicenna (Brill, 2003), p. 258. See also Herman G.B. Teule in, J. Van Ginkel et al., eds., Redefining Christian Identity (Leuven, 2005), pp. 167-184.

44 ZFRN 392 and MGMT 127, both 20th-century manuscripts. On the author, see Baumstark, GSL, p. 327. 
also pointing out two contemporary (18th century) copies of the Garšunī version of this work, translated from Syriac by Al-Ṭūrānī's pupil, Athanasios Aṣlan (SOAH 3, SOAA 63). Five of his homilies in Syriac ${ }^{45}$ are available in MGMT 17,46 and from Dayr Al-Za'farān (ZFRN 42) we have a collection of homilies in Garšūnī. Of his polemical work in Garšunī, with the catchy title of The Weapon of

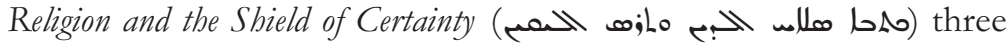
copies are available for study at HMML: ZFRN 70, 76; and USJ 975. Finally, and tangentially, there are also copies of his Kurdish hymn, recorded in Syriac letters, known simply as the Law ${ }^{47}$ Finally, I mention his Syriac memre. The 19th-century manuscript ZFRN 70 just mentioned above contains his memra On the End, the

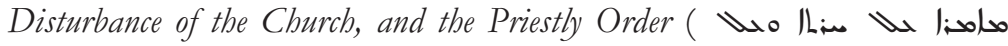

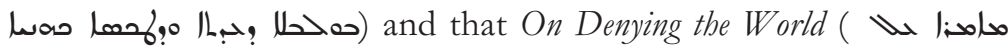

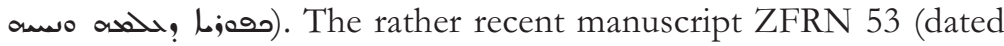
1971) also contains the former poem, as well as several shorter poetic pieces and a longer acrostic memra simply entitled On Himself

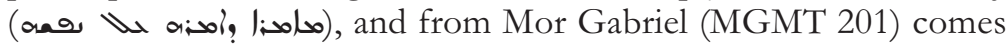
a manuscript of the same year also containing these texts. Very little of Al-Ṭürānī's literary output has been published, but thanks to the availability at HMML of these manuscripts, with certainly more to be found in the future, scholars interested in the more recent literature of the Syriac Orthodox Church and in a later stage of the language are in a suitable position to begin studying this writer and his time period more.

Finally, I would like to highlight some non-Syriac items of definite or possible connection to Syriac literature and thought. I have already named a few Garšūnī works, some by authors who also wrote in Syriac, some translated from Syriac, but all by nature intended for readers who knew Syriac script. Another Garšūnī text that I have yet to mention is the Arabic version of Jacob of

45 On the Talents (p. 1), On the Last Penny (p. 27), On the Wings of the Seraphim (p. 37), On the Lord's Prayer (p. 76), On the End (p. $110)$.

${ }^{46}$ (Pt. 2), pp. 1-156; the manuscript contains two works and each is paginated separately; the homilies are the second work.

47 Published and translated by P. Kreyenbroek in Journal of Kurdish Studies 1 (1995). There are also other texts and notes in this Syro-Kurdish among the west Syriac collections available at HMML, as well as Turkish texts written in Syriac script. 
Edessa's Hexaemeron, previously known in Garšūnī from one Paris and two Sbath manuscripts, and in Arabic script from Ming. Chr. Arab. 51. One of the Sbath manuscripts is now available at HMML (GAMS 945), but to this list for Garšunin and available at HMML may now be added a 17 th century manuscript belonging to the Lebanese Maronite Missionary Order (no. 30) and a 17th/18th century manuscript from Dayr Al-Za'farān (ZFRN 394). Turning to Gə'əz, I first only remark that the genres of both anaphorae and hagiography deserve further plundering with respect to textual relationships, often via an Arabic intermediary, to be sure, and the vast already cataloged collection of Gə'əz manuscripts available at HMML combined with the increasingly cataloged collection of Syriac (and Arabic/Garšunī) manuscripts there is ripe for such research. Secondly, I urge those scholars who work with both Syriac and Ga'oz to further examine the compositions attributed in that language to Ephrem and Jacob of Serug. While some of those Ethiopic works are doubtlessly falsely attributed, there really has been so little work on these texts by scholars competent in both languages (and in Arabic) that we cannot say much more than that. As a glimmer of the fruit that might be borne, however, from investigations of this kind, I point out that, contrary to statements in the scholarly literature, Jacob of Serug's Homily on the Death of Aaron ${ }^{48}$ is in fact extant in Ethiopian Christian tradition and not just the Falasha or Betä Isra'el community, namely in EMML 1939, ff. $114 \mathrm{r}-123 \mathrm{v}$, a 14th/15th c. manuscript, at the Monastery of Hayq Bstifanos at the time it was microfilmed.49 Graf (GCAL I.449)

48 The Syriac homily is no. 5 in Bedjan's ed. Kristian Heal is now working on a translation to be published in Gorgias Press's series of Jacob's homilies.

${ }^{49}$ This manuscript is cataloged in EMML Cat., vol. 5, pp. 429-433. Attention was first drawn to the Ethiopic text in Max Wurmbrand, "Homélie de Jacques de Saroug sur la mort d'Aaron," L'Orient Syrien 6 (1961): 255-278. He refers to two Faitlovitch manuscripts-these manuscripts are now in Tel Aviv, but microfilms are available for study at HMML- that contain the work, but not with shelfmarks. A microfilm of at least one of these manuscripts, Faitlovitch 8 (ff. 15a-40a), is, however, available at HMML. Wurmbrand gives parts of the homily translated into French from one of the Faitlovitch manuscripts and one Arabic manuscript (BNF 153); he of course did not know about the EMML manuscript, but more recently Witakowski (Encyclopaedia Aetbiopica, ed. Siegbert Uhlig et al., vol. 3 [Wiesbaden, 2007], p. 263) seems also not to 
indicates several manuscripts containing this homily in Arabic or Garšūnī, but I would add to his list two more Garšunini copies of the homily in HMML's collection from Homs (SOAH 2 and 22).

I conclude with the paraphrase of a paragraph written in 1980 for a report on the Ethiopian Manuscript Microfilm Library (EMML) project; the report was penned and delivered by William Macomber, to whose stature, although in some ways his successor at HMML, I make no semblance of any claim: This brief summary certainly does not exhaust the treasures that have already been unearthed in the HMML collection, but it will suffice, I trust, to give some idea of its true significance for Syriac studies. Other catalogers and I are constantly making new discoveries, and it can be reasonably hoped that this success will continue in the future. ${ }^{50}$

know of the EMML manuscript: After referring to this homily and to Wurmbrand's article on it, Witakowski says, "Its Christian original has not been identified, although a Christian Arabic translation (from Syriac) is known (GrafLit I, 449)." I am not certain what he means by "without attribution to J.S." The Faitlovitch manuscript to which I have access clearly has Jacob's name in the title. Wurmbrand leans toward translation from Arabic rather than Syriac, but admits the question cannot be decided for certain yet.

${ }^{50}$ For the original shape of Macomber's words, see "The present state of the microfilm collection of the Ethiopian Manuscript Microfilm Library," in Goldenberg, ed., Ethiopian Studies. Proceedings of the sixth international conference, Tel-Aviv, 14-17 April 1980 (Rotterdam and Boston: A.A. Balkema, 1986), p. 392. 



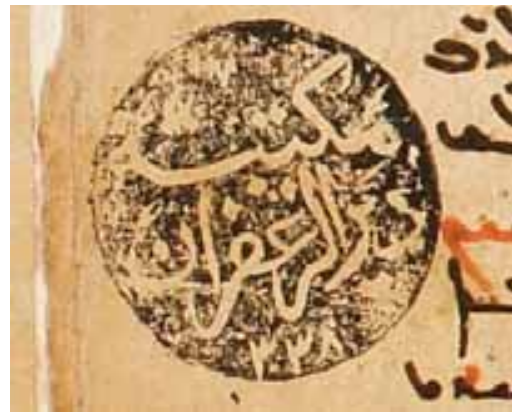

Figure 1: Dayr Al-Za'farān seal in CFMM 429, p. 373.

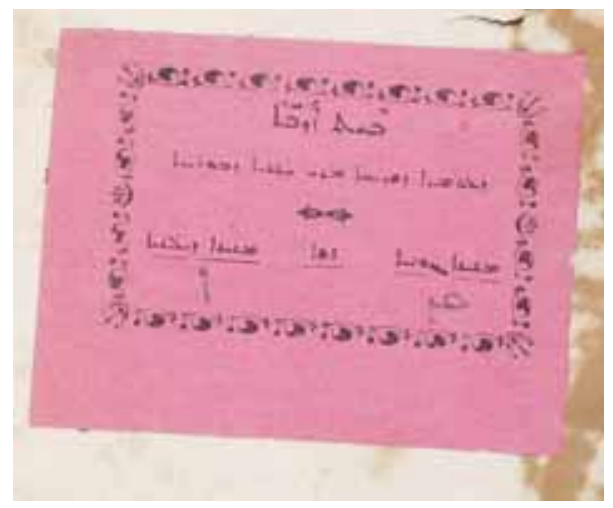

Figure 2: Bookplate in CFMM 421, inside cover.

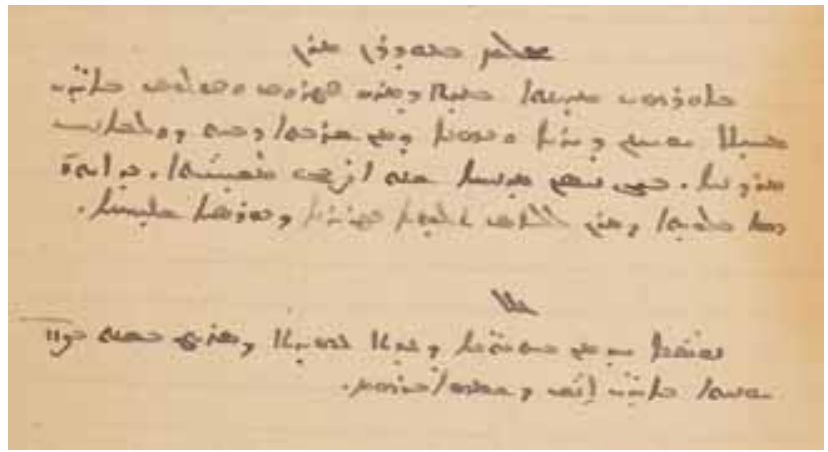

Figure 3: Colophon by Dolabani. CFMM 421, inside cover. 


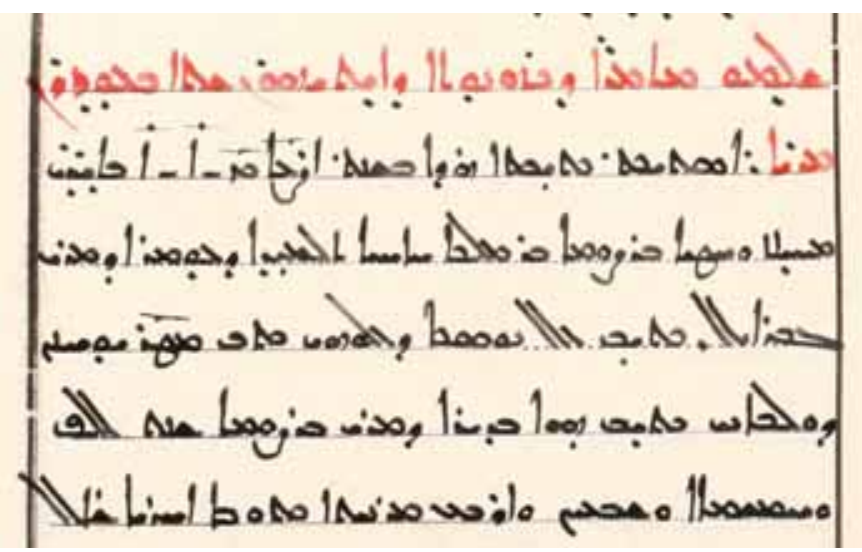

Figure 4: Colophon by Barșawmā bar Malke. MGMT 83, p. 183.

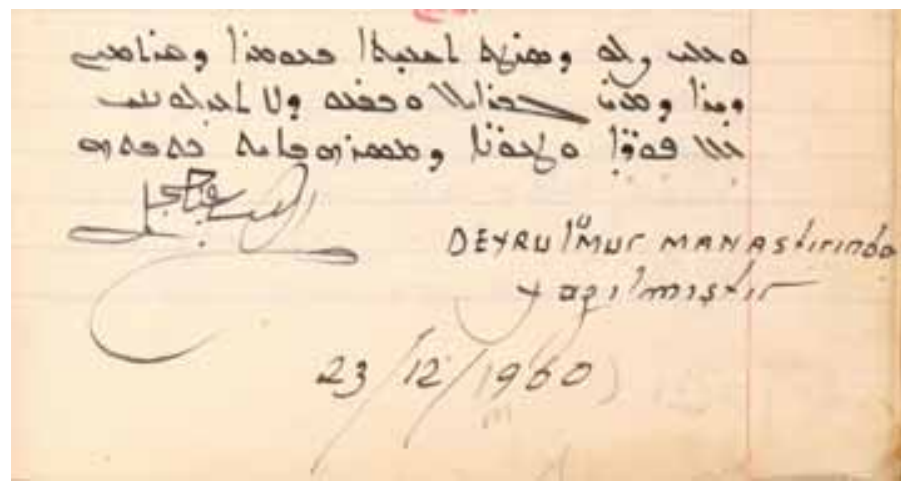

Figure 5: Colophon by Çiçek. MGMT 217, f. 94v. 


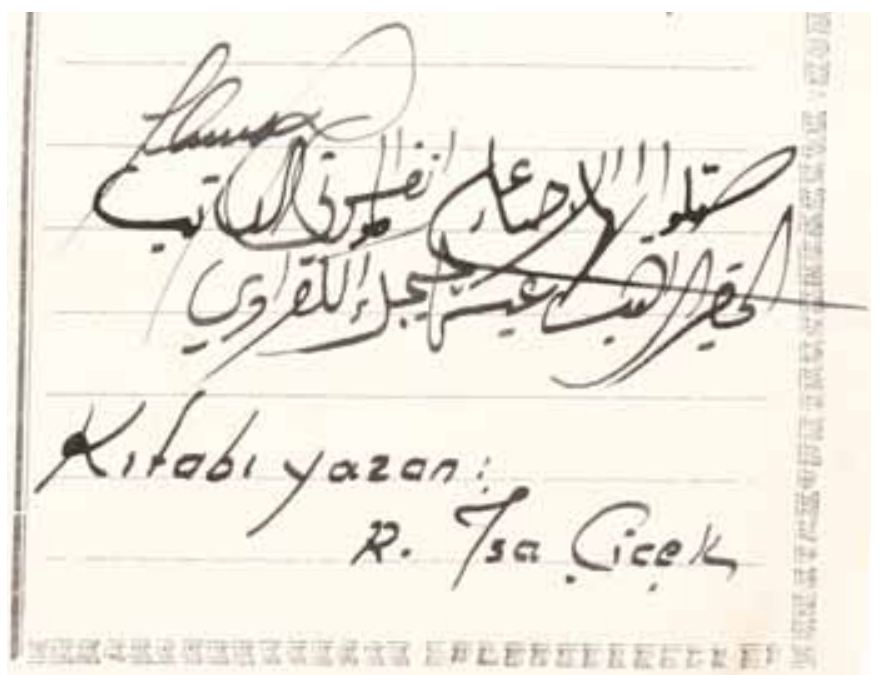

Figure 6: Colophon by Çiçek. MGMT 80, p. 317.

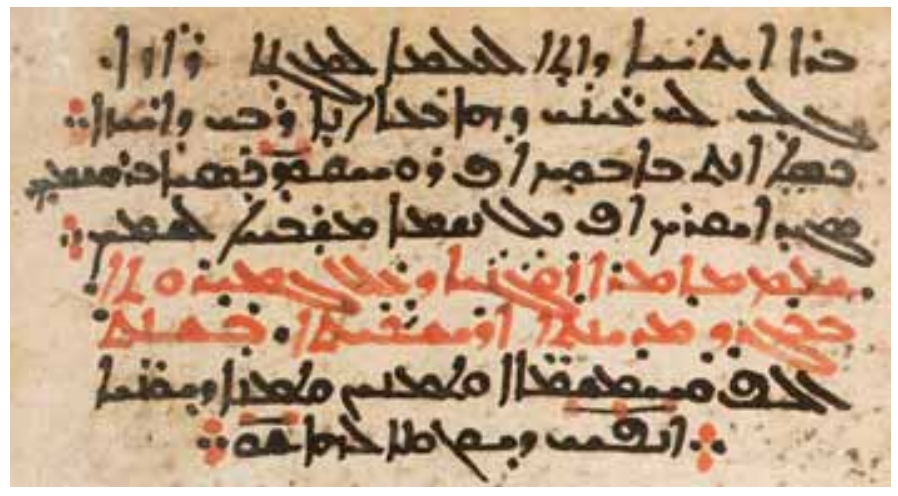

Figure 7: End of “On Perfection” in SOAA 148, f. 20 r. 
